\title{
Hydrochemical Analysis of Leachate Characteristics from Landfill Sites in Kaduna, Nigeria
}

\author{
Olaniyan, Isaac $\mathrm{O}^{1}$, Ayinla, Ibrahim $\mathrm{A}^{2}$. And Bashir Abdul ${ }^{3}$ \\ 1, 2, 3 Department of Agricultural Engineering, Kaduna Polytechnic, Nigeria
}

\begin{abstract}
The increase in solid waste generation in Nigeria, especially in urban cities, has become a major environmental problem resulting from high population growth rate and poor management of solid wastes. The absence of sanitary landfills has led to the emergence of several open waste dumps in towns and cities which constitutes potential threat to surface and groundwater systems. Prior to the design of a sanitary landfill facility for Kaduna, this study attempts to analyze the characteristics of leachate from landfill sites in order to determine its potential ability to contaminate surface and groundwater resources. Soil samples were taken from 19 selected municipal waste dumpsites using spot sampling procedure to determine the leachate characteristics. Soil samples were also taken from places adjacent to some landfill sites for comparison. Results of chemical analyses of soil extract constituents showed that, of the 20 hydrochemical parameters tested in the laboratories, the concentrations of only carbonates, bicarbonates and calcium ions had values below the international standard limits for drinking water, while the range of values for other parameters exceeded international standard limits; there were no traces of manganese in all the samples. Soil constituents from waste dumpsites were found to be significantly influenced by the characteristics of the solid wastes. The risks associated with the present poor system of waste management is very high as it constitutes threat to surface and groundwater resources.
\end{abstract}

Keywords: Solid wastes, sanitary landfill, leachate characteristics, water contamination.

\section{Introduction}

Solid waste generation has increased significantly especially in urban centres, and has become a major environmental problem resulting from high population growth and poor management of solid wastes. Apart from the fact that there is a relationship between public health and improper storage, collection and disposal of solid wastes, ecological phenomena such as water and air pollution have also been attributed to improper management of solid wastes (Tchobanoglous et al, 1993). For instance, liquid from dumps and poorly engineered landfills has contaminated surface waters and groundwaters. In mining areas, the liquid leached from waste dumps may contain toxic elements, such as copper, arsenic and uranium, or it may contaminate water supplies with unwanted salts of calcium and magnesium. The technology for solid waste disposal includes incineration, composting and sanitary landfill. The current trend in solid waste management is the engineered disposal system called Sanitary Landfill, and it has wider application worldwide than the other two methods (Carra and Cossu, 1989; Olaniyan, 2011).

Kaduna, which derived its name from the Kaduna River, is located approximately on latitude $10^{\circ} 36^{\prime} \mathrm{N}$ and longitude $7^{\circ} 27^{\prime} \mathrm{E}$. It is a major commercial town in Nigeria, and is the nerve center for commerce in northern Nigeria, having been the capital of the defunct northern region. Kaduna has a large concentration of industries such as food manufacturing, textiles, oil mills, paper conversion, flour mills, breweries, poultry feed mills, pharmaceuticals, industrial chemicals, fertilizer, dyeing and leather works and the refinery/petrochemical plant (Parkman, 2002). The nature of wastes from these industries is no doubt, vast in diversity. The increasing population of workers in these industries as well as in the academic, financial, health and hospitality establishments has given rise to the generation of large amount of wastes, which has been difficult to manage with the present arrangements. This underscores the problem of waste management in Nigeria.

Kaduna State falls within the Guinea Savanna region with characteristic wet (rainy) season, which occurs usually between late April and early October, and dry season that lasts for the remaining period of the year. The spatial and temporal distribution of rainfall varies, decreasing from an average annual value of about $1530 \mathrm{~mm}$ in Kafanchan-Kagoro areas of the south east to about $1015 \mathrm{~mm}$ in Ikara-Makarfi districts in the north-east, with peak values occurring between July and August. Maximum temperatures often rise to about $38^{\circ} \mathrm{C}$ or more between March and April, and may drop significantly to about $24^{\circ} \mathrm{C}$ or less during peak rainy periods and during the dry, cold north-easterlies or harmattan winds in the dry season (FMI, 2000; Olaniyan and Olabode, 2012). The entire land area of Kaduna state is underlain by Precambrian migmatite-gneiss complex, metasediments/ metavolcanics (mostly schists, quartzites, amphibolites and Banded Iron formations), Pan-African granitoids 
and volcanics of Jurassic age towards the south-eastern border of the state (Oluyide, 1995). However, the characteristic Basement Complex rocks of the study area are the migmatites and gneisses, the metasediments and the Older granites. Basically, two types of aquifers may be identified in the study area: the fractured crystalline rock aquifer and the unconsolidated to semi-consolidated overburden aquifer. Both are assumed to be in hydraulic connection with unconfined to semi-confined conditions (Hazel et al, 1992).

This study attempts to analyze the characteristics of leachate from landfill sites, prior to the design of a sanitary landfill facility for Kaduna, in order to determine its potential ability to contaminate surface and groundwater resources. Four local government areas (LGAs), namely Kaduna North, Kaduna South, Chikun and Igabi LGAs are to benefit directly in the proposed sanitary landfill project (Figure 1).

\section{Materials And Methods}

For the purpose of this study, Kaduna metropolis was divided into three zones, namely north, south and central. Nineteen (19) soil samples which comprised of six from south and central zones and seven from north zone were collected underneath the landfills within $0-30 \mathrm{~cm}$ depth from the ground surface. Samples were prepared, digested, filtered and diluted to obtain stock sample solutions which were used to analyze twenty (20) hydrochemical parameters, namely $\mathrm{pH}$, electrical conductivity, total dissolved solids, alkalinity, acidity, total hardness, carbonate, bicarbonate, biochemical oxygen demand (BOD), chemical oxygen demand (COD), chloride, nitrate, sulphate, iron, calcium, magnesium, manganese, chromium, sodium and potassium. Another set of soil samples were taken from points adjacent to the waste dumpsites where soil samples were taken, with the aim of comparison and determining the extent to which municipal wastes have influenced soil characteristics, and only six parameters were tested, which are $\mathrm{pH}$, electrical conductivity, calcium, magnesium, sodium and potassium.

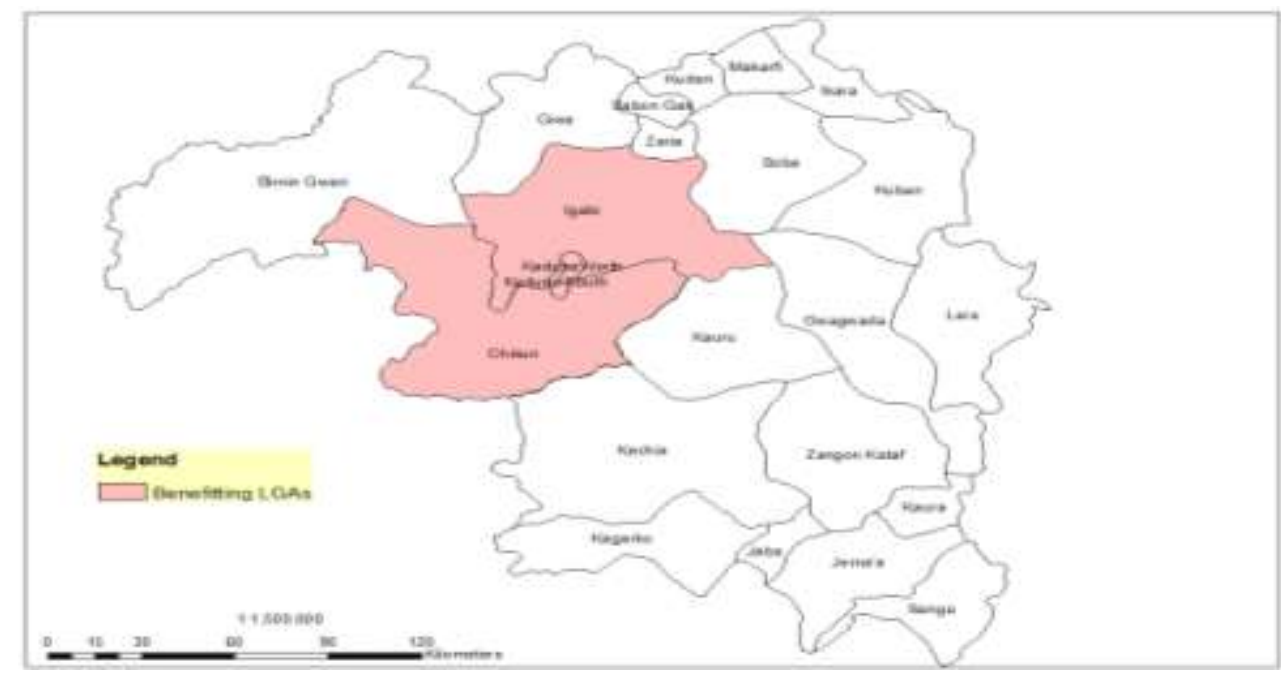

Figure 1: Map of Kaduna State of Nigeria Showing Benefitting Areas

\section{Results And Discussion}

The results of chemical analyses of soil constituents are presented as Table 1. Based on this result, the following deductions were made:

pH. The $\mathrm{pH}$ value of a solution is the negative logarithm of the concentration of hydrogen ions in moles per litre. From the result presented in Table 1, the $\mathrm{pH}$ values of soil constituents range from 6.58 to 8.58. When compared with World Health Organization (W.H.O.) international $\mathrm{pH}$ standard for drinking water (Table 2), the $\mathrm{pH}$ values are all within the maximum permissible limit. However, if these values can be maintained and monitored, there will be no significant threat to water resources quality in terms of $\mathrm{pH}$.

Total Dissolved Solids. The concentration of dissolved matter in water is given by the weight of the material on evaporation of the water to dryness followed by heating for one hour at $180^{\circ} \mathrm{C}$. The W.H.O. standard limit for drinking water is $500 \mathrm{mg} / \mathrm{l}$. The result obtained showed high values at some locations, especially at Ori-Apata, Barnawa, Kakuri, Costain and Kagoro Close, which exceeded the maximum permissible limit.

Total Hardness. This denotes the concentration of calcium and magnesium in water, and is usually expressed as the equivalent of $\mathrm{CaCO}_{3}$. Hardness is an important criterion for determining the usability of water for domestic, drinking and industrial supplies (Karanth, 1993). Soft water generally has values less than $60 \mathrm{mg} / \mathrm{l}$. Water used for boiler feed will cause excessive scale formation (carbonate mineral precipitation) if the hardness 
is above $60-80 \mathrm{mg} / \mathrm{l}$. The W.H.O. standard for drinking water is $100 \mathrm{mg} / \mathrm{l}$. These limits have been exceeded at 14 out of 19 sampling locations. This is apparently a threat to the quality of surface and ground water resources.

BOD and COD. The most widely used parameter of organic pollution applied to both wastewater and surface water is the 5-day biochemical oxygen demand $\left(\mathrm{BOD}_{5}\right)$. While the polluting strength of leachate or effluent is expressed as $\mathrm{BOD}_{5}$, the chemical oxygen demand (COD) test is a determination of the amount of a specific strong chemical oxidant that is reduced by a waste. The BOD value depends on organic constituents while COD value is dependent on both the organic and inorganic constituents. The COD of a waste is, in general, always higher than the BOD under the same conditions because more compounds can be chemically oxidized than can be biologically oxidized. Once the correlation has been established, COD measurements can be used to good advantages for treatment-plant control operation (Tchobanoglous and Burton, 1991). The BOD values range from $110 \mathrm{mg} / \mathrm{l}$ at Barnawa to $499 \mathrm{mg} / \mathrm{l}$ at Tudun-Wada while the COD values range from $198 \mathrm{mg} / \mathrm{l}$ to $749 \mathrm{mg} / \mathrm{l}$ at the same locations respectively. These values are evident of the potential for gross pollution if leachate finds its way into any surface water body.

Sulphate. Sulphates may originate from sulphides of heavy metals present in municipal wastes. When sulphides are oxidized, they give rise to soluble sulphates which make the receiving water have low $\mathrm{pH}$ and corrosive.

$$
\begin{array}{llll}
\text { i.e. } \quad 2 \mathrm{FeS}_{2}+7 \mathrm{H}_{2} \mathrm{O}+15 \mathrm{O} & \longrightarrow & 2 \mathrm{Fe}(\mathrm{OH})_{3}+4 \mathrm{H}_{2} \mathrm{SO}_{4} \\
\mathrm{FeS}_{2}+7 \mathrm{O}+\mathrm{H}_{2} \mathrm{O} & \longrightarrow \mathrm{Fe} \mathrm{SO}_{4}+\mathrm{H}_{2} \mathrm{SO}_{4}
\end{array}
$$

The W.H.O. highest desirable limit for drinking water is $250 \mathrm{mg} / \mathrm{l}$, which shows that waste constituents at Nasarawa, Ungwan Sarki, Abakpa, Bachama and Badiko indicated high levels of sulphate which should be monitored.

Chloride. Chloride salts, commonly sodium chloride, are highly soluble and free from chemical reactions with soil rock minerals, and so remain stable once they enter into solution. Abnormal concentrations may occur from municipal wastes, especially those containing coconut residue. The W.H.O. limit for drinking water was exceeded at Rigasa (266mg/l), Costain (1066mg/l), Abakpa (319mg/l), Bachama (447mg/l), Badiko (369mg/l) and Ungwan Sarki $(2236 \mathrm{mg} / \mathrm{l})$. These are potential sources of salinity in surface and groundwater systems which require monitoring and control.

Nitrate. Nitrate is an important contaminant in water. Excessive concentrations of nitrate have potential to harm infant babies and livestock if consumed on a regular basis. The greatest contribution of nitrate in surface and groundwater is from decaying organic matter, sewage wastes and nitrate fertilizers. The recommended limit in drinking water is $45 \mathrm{mg} / \mathrm{l}$ when expressed as $\mathrm{NO}_{3}{ }^{-}$or $10 \mathrm{mg} / \mathrm{l}$ when expressed as $\mathrm{N}$ (Table 2). The highest amount obtained from test results is $25 \mathrm{mg} / \mathrm{l}$, which is of great significance especially at Abakpa, Bachama, Badiko and Trikania dumpsites in comparison with the guideline value. However, occurrences of nitrate pollution may be controlled through cropping.

Carbonate and Bicarbonate. Apart from the atmospheric carbon dioxide in rain which dissolves more $\mathrm{CO}_{2}$ as it enters soil to form carbonate and bicarbonate, the decay of organic matter also releases carbon dioxide for dissolution. Water charged with carbon dioxide dissolves carbon minerals, as it passes through soil and rocks, to give bicarbonates. The values obtained from tests range from 0 to $781 \mathrm{mg} / \mathrm{l}$, while the W.H.O. guideline value is $500 \mathrm{mg} / \mathrm{l}$. With regard to the guideline value, the only location with excessive value is Costain.

Specific Electrical Conductance. Conductivity refers to the conductance of a cube of one centimeter side of a substance and is reported in mhos $/ \mathrm{cm}$, or micromhos $/ \mathrm{cm}$. The presence of dissociated ions in water renders it conductive, although different salts have different conductivities for a given concentration. High values were obtained at Abakpa (1012 $\mu \mathrm{mhos} / \mathrm{cm})$, Badiko (1340 $\mu \mathrm{mhos} / \mathrm{cm})$, Costain (1420 $\mu \mathrm{mhos} / \mathrm{cm})$, Barnawa (1700 $\mu \mathrm{mhos} / \mathrm{cm}$ ) and Ori-Apata (2400 $\mu$ mhos/cm).

Calcium. Calcium is a major constituent of most igneous, metamorphic and sedimentary rocks. Calcium carbonate dissolves continuously in the presence of water containing carbon dioxide in dissolved form, but may be precipitated again once the acid is used up.

$$
\mathrm{CaCO}_{3}+\mathrm{H}_{2} \mathrm{O}+\mathrm{CO}_{2} \longrightarrow \mathrm{Ca}\left(\mathrm{HCO}_{3}\right)_{2}
$$

The international standard limit of calcium in drinking water is $200 \mathrm{mg} / \mathrm{l}$, whereas the highest values encountered from samples are 256, 276, $248 \mathrm{mg} / \mathrm{l}$ at Abakpa, Bachama and Badiko areas respectively which shows that calcium contents of municipal waste in Kaduna are not within acceptance levels at some areas, and may further accumulate to higher levels. 

TABLE 1: RESULTS OF CHEMICAL ANALYSES OF SOIL CONSTITUENTS

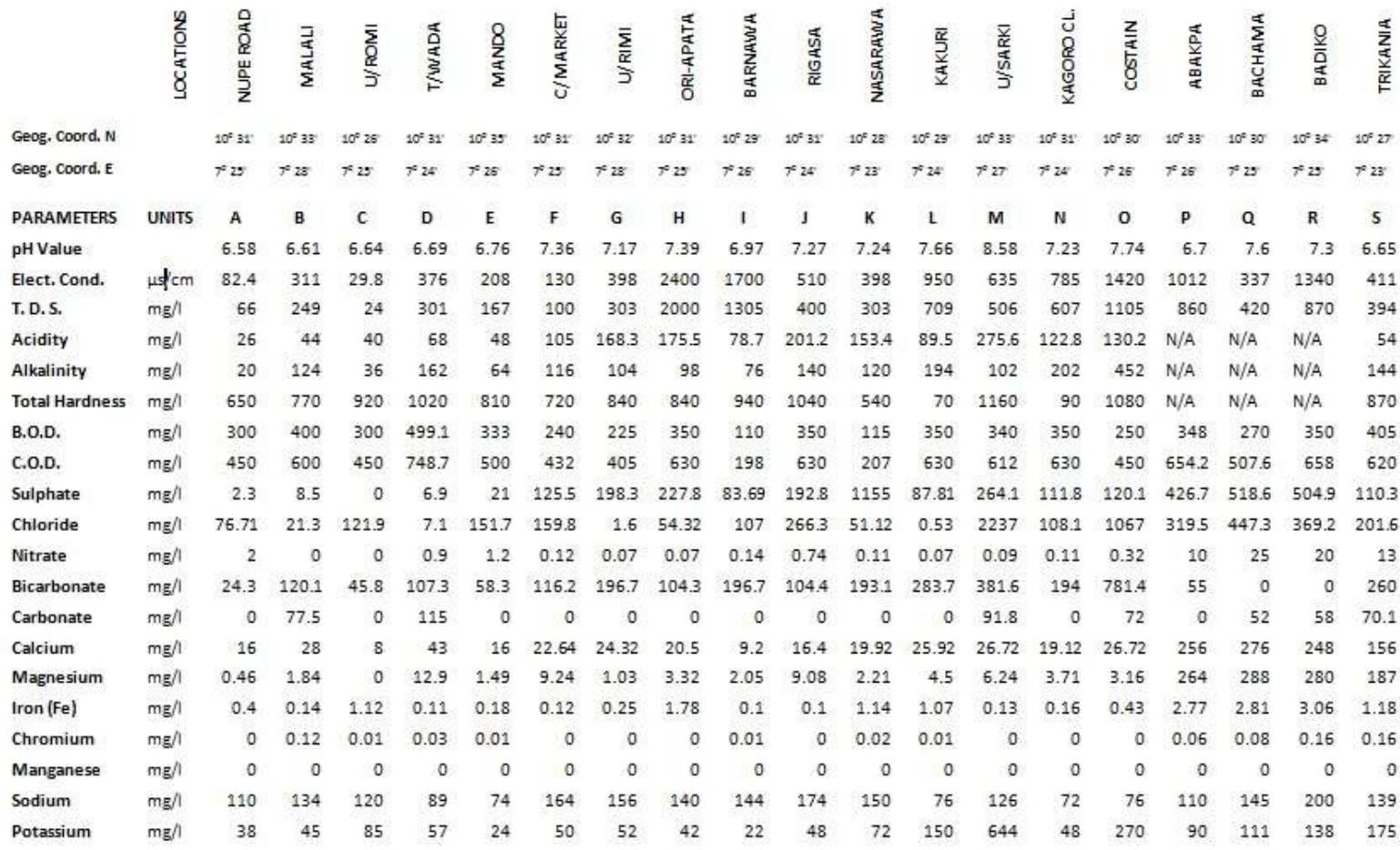

TABLE 2: Standards for Chemical Quality of Drinking Water Compared with Maximum Leachate

\begin{tabular}{|c|c|c|}
\hline Substances & $\begin{array}{l}\text { W.H.O. Maximum } \\
\text { Guideline Value }\end{array}$ & $\begin{array}{l}\text { Kaduna Maximum Leachate } \\
\text { Concentration }\end{array}$ \\
\hline B.O. $\mathrm{D}_{5}(\mathrm{mg} / \mathrm{l})$ & 6.0 & 499.1 \\
\hline C.O.D $(\mathrm{mg} / \mathrm{l})$ & 10.0 & 748.7 \\
\hline $\mathrm{pH}$ & $6.5-8.5$ & 8.58 \\
\hline T.D.S. $(\mathrm{mg} /)$ & 500 & 2000 \\
\hline Elect. Cond. ( $\mu \mathrm{mhos} / \mathrm{cm})$ & - & 2400 \\
\hline Total Hardness as & & \\
\hline $\mathrm{C}_{3} \mathrm{CO}_{3}(\mathrm{mg} /)$ & 100 & 1155 \\
\hline Acidity $(\mathrm{mg} / \mathrm{l})$ & 500 & 275.6 \\
\hline Alkalinity (mg/1) & 500 & 452 \\
\hline Sulphate (mg/1) & 250 & 1155 \\
\hline Chloride (mg/) & 250 & 2237 \\
\hline Fluoride (mg/) & 1.4 & - \\
\hline Nitrate (mg/) & 10 as $\mathrm{N} ; 45$ as $\mathrm{NO}_{3}^{-}$ & 25 \\
\hline Bicarbonate (mg/) & 500 & 781.4 \\
\hline Carbonate (mg/) & 500 & 115 \\
\hline Calcium (mg/1) & 200 & 276 \\
\hline Magnesium (mg/1) & 150 & 288 \\
\hline Iron as $\mathrm{Fe}^{2+}(\mathrm{mg} /)$ & 0.3 & 3.06 \\
\hline Manganese (mg/) & 0.1 & 0 \\
\hline Chromium(mg/) & 0.05 & 0.16 \\
\hline Sodium (mg/) & 200 & 200 \\
\hline Potassium (mg/) & 15 & 644 \\
\hline $\mathrm{Zinc}(\mathrm{mg} / \mathrm{l})$ & 5.0 & - \\
\hline Copper (mg/) & 1.0 & - \\
\hline Mercury (mg/) & 0.001 & - \\
\hline Arsenic (mg/) & 0.05 & - \\
\hline Lead $(\mathrm{mg} / \mathrm{l})$ & 0.05 & - \\
\hline
\end{tabular}

Source: World Health Organization International Standards, 1971 
Magnesium. Magnesium is an important component of most rocks, and it occurs in the form of insoluble silicates, which become more soluble carbonates as they are weathered. In the presence of carbonic acids in water, magnesium carbonate is converted into soluble bicarbonate.

$$
\mathrm{MgCO}_{3}+\mathrm{CO}_{2}+\mathrm{H}_{2} \mathrm{O} \longrightarrow \mathrm{Mg}\left(\mathrm{HCO}_{3}\right)_{2}
$$

The W.H.O. maximum permissible limit is $150 \mathrm{mg} / \mathrm{l}$, while the highest values obtained in all the 19 samples analyzed were 264, 288, 280 and $187 \mathrm{mg} / \mathrm{l}$ at Abakpa, Bachama, Badiko and Trikania respectively.

Chromium. Chromium, like other trace constituents, normally occur in indeterminate quantities or traces generally not exceeding $1.0 \mathrm{mg} / \mathrm{l}$. Chromium is a toxic constituent, and its common mineral is an oxide. Although it occurs in small quantities, groundwater may accrue chromium through disposal of waste. The mandatory limit for chromium in drinking water is $0.05 \mathrm{mg} / \mathrm{l}$. However, Malali, Abakpa, Bachama, Badiko and Trikania are the only locations with values of $0.12,0.06,0.08,0.16,0.16 \mathrm{mg} / \mathrm{l}$ respectively which are above the limit values. This indicated potential threat to water resources especially for groundwater if chromium level accumulates.

Iron. Iron occurs naturally in rocks and soil but is also attainable in water with low $\mathrm{pH}$ (acid waters), especially those derived from swamps and peat bogs. Iron occurs in groundwater in the form of ferric hydroxide in concentrations less than $0.05 \mathrm{mg} / \mathrm{l}$. Ferrous iron content may, however, be reduced in water by aeration. The W.H.O. standard limit for iron content in drinking water is $0.30 \mathrm{mg} / \mathrm{l}$. Nine locations showed excessive iron levels as high as 1.78, 2.77, 2.81 and $3.06 \mathrm{mg} / \mathrm{l}$. If this concentration flows continually and uncontrollably as leachate into surface and groundwater systems, there will be the risk of contamination.

Manganese. Manganese accumulates in residual deposits such as laterite and soil, and they occur only in metamorphic and sedimentary rocks as oxides, hydroxides, carbonates and silicates. Manganese occurrence is less widespread than that of iron. Under reducing conditions and low $\mathrm{pH}$, higher manganese content may be attained. Even though the permissible limit is $1.0 \mathrm{mg} / 1$, there was no indication of any manganese concentration in all the samples analyzed. Sodium Adsorption Ratio (S.A.R.). Sodium adsorption ratio is generally a good indicator of sodium hazard in water. When exchangeable sodium occurs in irrigation water and soil at high concentrations, it causes eventual deterioration of soil structure and a resulting reduction in hydraulic conductivity. The S.A.R. is defined by $S . A . R .=N a /(1 / 2 \sqrt{(C a+M g)})$, where all ion concentrations are expressed as equivalents per million $[=(\mathrm{mg} / \mathrm{l}) /$ atomic weight]. Generally, water with $\mathrm{SAR}<10$ is low sodium water, 10-18 is medium, $18-26$ is high, and SAR $>26$ is very high sodium water. From the results in Table 1 , all the SAR values are generally above 10, except for Abakpa dumpsite which is slightly below 10 with a value of about 9.65. The leachate is expected to have very high sodium contents. Such water will present an appreciable sodium hazard in fine-textured soils with high cation exchange capacity, especially under low leaching conditions, unless gypsum is present in the soil. This water may, however, be used on coarse-textured or organic soils with good permeability.

\section{Comparison Of Chemical Analyses Of Soil Constituents From Dump Sites With Those From Adjacent Soils}

The results of chemical analyses of constituents of soils adjacent to the waste dump sites are as presented in Figure 2. A cursory look at the results in comparison with corresponding results in Table 1 shows significant differences in values of chemical constituents, and this provides convincing evidence that the constituents of soils at waste dump sites have been significantly influenced by the characteristics of solid wastes dumped at those sites. This makes the need for this study both imperative and inevitable, and also provides further evidence of the potential threat of such dumps to surface and ground water quality.

The quality of irrigation water is determined not only by the total concentration of ions, but also by the individual ions present. The most common cations in irrigation water are calcium, magnesium, sodium and potassium. Although many tree crops are sensitive to sodium, the major concern from high concentrations of sodium in soils and irrigation waters is the eventual deterioration of soil structure, resulting in decreased water infiltration and permeability. The most common anions are bicarbonate, sulphate and chloride, while other solutes such as nitrate, carbonate and trace elements may also affect water quality in some instances. High nitrate levels in irrigation water are beneficial to crop production, but can potentially degrade groundwater quality (Jensen, 1983). 


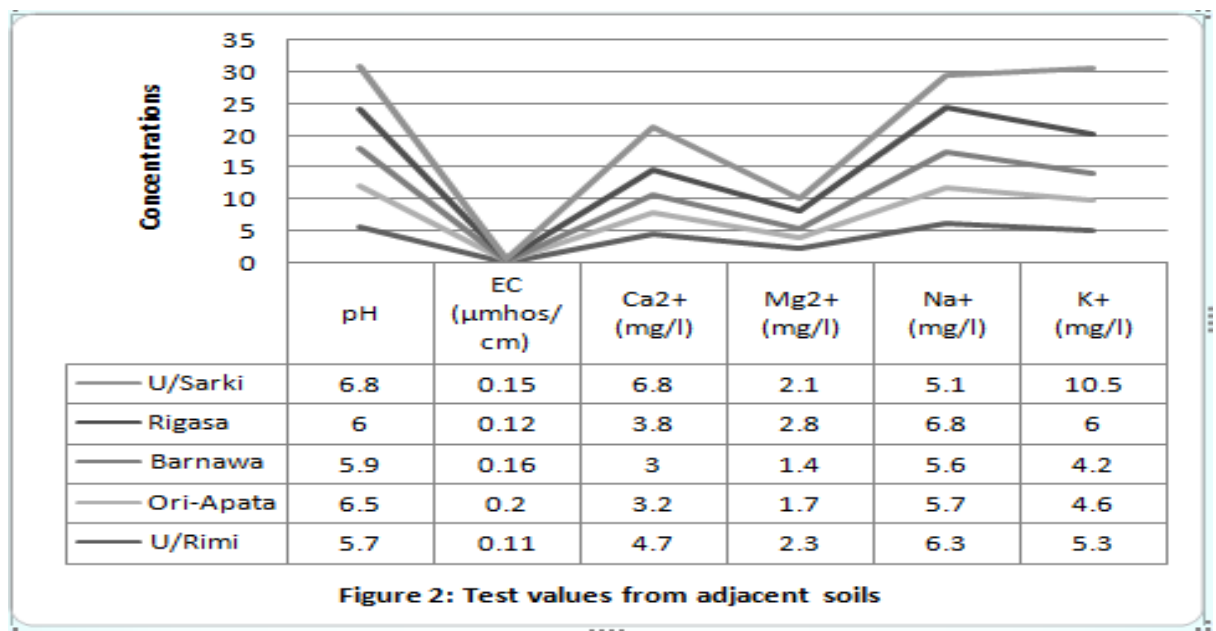

V. Irrigation Water Quality And Leachate Contamination

From table 1, the concentrations of sodium, chloride and bicarbonate ions are excessively high for irrigation purposes, and these conditions may create severe irrigation water quality problems with crop production limitations if leachate migration into surface and groundwater are left unchecked. Therefore, to avoid salinity build-up, adequate drainage and good soil structure should be maintained through regular programme of salinity monitoring, management and reclamation, particularly with respect to water sources prone to contamination from waste dumpsites.

\section{Conclusion}

The hydrochemical characteristics of leachate from landfill sites were determined in order to ascertain its potential ability to contaminate surface and groundwater resources by using soil samples. The study revealed that poor management of municipal wastes constitutes a threat to the quality of surface and groundwater resources. Therefore, it is imperative to design and construct more environment-friendly sanitary landfills with good engineering control, especially in the urban centers across Nigeria.

\section{References}

[1] Carra, J. and Cossu, R. (1989). International perspectives in waste management and landfilling: Academic Press Ltd., London.

[2] Federal Ministry of Information (2000). NIGERIA: A people united, a future assured. Vol. 2, Survey of states.

[3] Hazel, J.R.T., Cratchley, C.R. and Jones, C.R.C. (1992). "The hydrogeology of crystalline aquifers in northern Nigeria and geophysical techniques used in their exploration". In: Wright, E.P. and Burgess, W.G. (Eds): Hydrogeology of Crystalline Basement Aquifers in Africa. Geol. Soc. Special publication No. 66, London pp. 155-182.

[4] Jensen, M.E. (Ed.) (1983). Design and operation of farm irrigation systems. Revised edition. An Michigan, U.S.A., pp.166 - 173.

[5] Karanth, K.R. (1993). Groundwater assessment, development and management. Tata McGraw-Hill Publishing Co. Ltd., New Delhi. Pp. 217-275, 510-548

[6] Olaniyan, I.O. (2011). Surface and ground water contamination from landfill: A model study.

LAP LAMBERT Academic Publishing, Saarbrucken, Germany, 136pp

[7] Olaniyan, I.O. and Olabode, T.O. (2012). Assessment of groundwater potential of a typical 'fadama' in Kaduna state, Nigeria. RESEARCHER 4(4):10-15 Marsland Press, New York, U.S.A. http://www.sciencepub.net

[8] Oluyide, P.O. (1995). Mineral occurrences in Kaduna state and their geological environments. Proc. of workshop held by NMGS, Kaduna Chapter in collaboration with Kaduna State Government, 15 December, pp. 13-27.

[9] Parkman Nigeria Limited (2002). Study for construction of integrated waste management facility in Kaduna. First Progress Report: Site selection and waste generation survey, Federal Ministry of Environment, Nigeria, 68pp.

[10] Tchobanoglous, G. and Burton, F.L. (1991). Wastewater engineering treatment, disposal and re-use, 3rd Ed., McGrawHill Inc.

[11] Tchobanoglous, G., Theisen, H. and Vigil, S. (1993). Integrated solid waste management: Engineering principles and management issues. McGraw-Hill Inc. New York, pp.5,15-16

[12] World Health Organization (1971). International standards for drinking water, Geneva 